\title{
EXPLORING ISLAMIC BANKING SWITCHING INTENTION
}

\author{
Miftah Barid1', Siswanto², Masyhuri ${ }^{3}$ \\ 1,2 State Islamic University, Maulana Malik Ibrahim Malang, Indonesia \\ ${ }^{3}$ Islamic University of Malang, Indonesia
}

$凶$ Corresponding Author:

Nama Penulis: Siswanto

E-mail: siswanto@pbs.uin-malang.ac.id

\section{Abstract}

Islamic banking is developing quite rapidly, but its market share is still far behind conventional banks. The movement of customers from conventional banks to Islamic banks must be continuously improved. The transfer of conventional bank customers to Islamic banks is determined by the intention to move (Switching intention). Switching intention is an individual's desire or intention to switch services and is described as a signal and opportunity for customers to switch to new services. This study aims to analyze the factors that affect the switching intention of customers of Islamic banks in Malang City with a theory of planned behavior. This study uses a quantitative approach. The number of samples is 100 respondents. Data analysis using confirmatory factor analysis (CFA). The analysis results show that attitude, subjective norm, and perceived behavior control influence the switching intention of Islamic banks in Malang City. The attitude variable is the dominant factor affecting switching intention.

Keywords: Attitude; Subjective Norm; Perceived Behavioral Control, Switching Intention.

\section{Abstrak}

Perbankan Islam bekembang cukup pesat, namun market sharenya masih terpaut jauh dengan bank konvensional. Perpindahan pelanggan dari bank konvensional ke bank syariah harus terus ditingkatkan. Perpindahan nasabah bank konvensional ke bank syariah ditentukan oleh niat untuk berpindah (Switching intention). Switching intention merupakan hasrat atau niat individu untuk beralih layanan dan digambarkan sebagai sinyal dan peluang nasabah untuk beralih ke layanan yang baru. Penelitian ini bertujuan untuk menganalisis faktor-faktor yang mempengaruhi switching intention nasabah bank syariah Kota Malang dengan theory of planned behavior. Penelitian ini menggunakan pendekatan kuantitatif. Jumlah sampel sebanyak 100 responden. Analisis data menggunakan confirmatory factors analisis (cfa). Hasil analisis menunjukkan bahwa attitude, subjective norm dan perceived behavior control merupakan faktor yang berpengaruh terhadap switching intention pada bank syariah Kota Malang. Variabel attitude merupakan faktor dominan yang mempengaruhi switching intention.

Kata kunci: Attitude; Subjective Norm; Perceived Behavioral Control, Switching Intention. 


\section{INTRODUCTION}

Islamic banking is a financial institution whose operations are carried out with sharia principles or Islamic principles. The establishment of a sharia bank begins with the public's desire to avoid muamalah transactions prohibited in Islam, such as usury, gharar, and muamalah transactions that harm others. Islamic banks in Indonesia have developed quite rapidly. As of November 2018, it was recorded that the national Islamic banking assets were IDR 451.20 trillion. However, in terms of market share, Islamic banks can still be small, namely $5.725 \%$. If this is compared to the market share of conventional banking, which is 95.2 percent (Wimboh, 2020). In addition, the total customers of Islamic and conventional banks are still far apart. It was recorded that in 2019 the Financial Services Authority stated that Islamic bank customers had only reached 31.89 million people. Meanwhile, conventional banks have 292.68 million active customers. Of course, this is a particular concern for Islamic banks always to pay attention to their business aspects. So that conventional customers are interested in switching (switching behavior) to Islamic banks.

Switching behavior is largely determined by intention (switching intention). The greater the intention of someone to switch to Islamic banking, it is hoped that it can be successfully displayed in action. Jabeen et al., (2015) Switching intention or intention to switch customers is a sign of partial or total cessation of customer relationships with current service providers. Partially this will occur if the customer maintains a relationship with the current service provider as well as looking for other service providers. Roos et al., (2004) categorize customer switching into two, namely internal and external. Internal customer switching occurs when a customer switches to another product or service but is still within one company's scope. Meanwhile, external customer switching occurs when customers switch to using alternative products or services outside the current company.

Theory of behavioral control (TPB) that a person's intention in something can be seen from his subjective attitudes, norms, and perceived behavior control (Arwani, 2015). Attitude arises from the person's intention, while subjective norms are related to the perception that he believes that comes from the surrounding environment. Besides that, the intention is also influenced by perceived behavior control or behavior control (Kaur \& Arora, 2020). There are three types of intentions or interests. First, intention is defined as the expectation to do something. Second, intentions are interpreted as the desire to do something. Third, intentions are interpreted as a plan to do something.

Previous research results from Farah, (2017), Madahi \& Sukati, (2016), and Youn et al., (2021) stated that attitude and subjective norms can predict switching intention. As well as Dinaratu, (2017) found that the young age range which students dominated and university students actually contributed the least to the percentage of customer data in Islamic banks, even though young people such as students played an important role in attracting the general public who still used conventional banks to switch to Islamic banks. 
It is known that a contradiction in the results of previous research with the theory of planned behavior formulated regarding switching intention. This is undoubtedly a research gap for researchers to research switching intention. So that the purpose of this study is to determine the factors that can affect the switching intention of Islamic Bank Malang City.

\section{LITERATURE REVIEW}

\section{Theory Of Planned Behavior}

Theory of planned behavior (TPB) is a theory developed by Ajzen and Feashbien to complement the reasoned action theory in predicting individual behavior. This theory complements the previous theory by adding behavioral control as a factor that influences an individual's intentions and subjective attitudes and norms. In this TPB theory, a person's behavior is described as a state that is described in a conscious state. That is, someone's behavior can be done with careful planning or thought. This theory rests on the idea that humans are creatures who think and can act out the information that comes to him and the consequences if he behaves with this information (Ajzen, 1991, 2020; Ajzen \& Kruglanski, 2019; Ajzen \& Schmidt, 2020).

According to this theory, the most determining factor in behavior is the intention to behave. The intention is described as motivation, which contributes significantly to displaying behavior. The greater the intention to behave, the more likely it is to succeed in doing it. The intention is an indicator of how serious an individual is in displaying a behavior. Generally, if a person desires to perform a behavior, there will be a tendency to do so. The intention to behave can be said to be a description of the behavior that arises from an individual if it is under control, or it can be said that the individual has the consideration to do so or not.

The theory of planned behavior has three variables. First, attitude, namely the level of a person having a good or bad assessment of behavior. Second, social factors are often called subjective norms, namely things that refer to the decision to accept social pressure to do or not to do certain behaviors. Third, the control of behavior or the level of feelings refers to the perceived ease or difficulty in carrying out the behavior and reflects past experiences and how to anticipate these obstacles (Ajzen, 1991).

\section{Attitude}

According to Azjen, (1980), attitude is a psychological tendency expressed by evaluating certain entities with various measures, likes, and dislikes. While Kotler et al. (2019) state that attitude is an evaluation of liked or disliked, emotional feeling, and the tendency to act on an object or idea. Someone has an attitude towards almost everything, be it religion, politics, clothes, music, and clothes.

According to Ajzen, (1991) attitudes develop naturally from the beliefs held by a person. The formation of this belief is associated with specific attributes, for example with objects, characteristics, or other events. The formed attitudes are often associated with beliefs about behavior and the 
results obtained from certain behaviors or other attributes such as the costs that must be incurred when carrying out certain behaviors. Because the attributes associated with certain behaviors have been valued positively or negatively, an attitude automatically emerges.

\section{Subjective Norm}

According to Ajzen and Fishbein behavioural control is a factor that affects intention (Bansal et al., 2005). The definition of behavioural control is a subjective norm, which is a person's perception of social pressure aimed at the individual to perform certain behaviors. According to Ajzen, (1971) Subjective norms consist of two sub-components. First, Normative belief is a normative associative belief, which reflects a person's perceptions in terms of whether or not that person should do certain behaviors based on suggestions from others. Second, motivation to comply is what motivation underlies the person to obey the suggestions of those around him. The motivation to be seen in two different ways. First, the person's motivation to submit to a particular group's suggestions, regardless of the specific demands put forward through that suggestion., the person may not want to behave following any of the group's specific expectations.

\section{Perceived Behavior Control}

According to Ajzen (1991) Behavioral control is closely related to beliefs about the presence or absence of the necessary resources and opportunities. The emergence of this belief is usually based on past experiences. In addition, it will usually be influenced by second-hand information such as experiences shared by acquaintances, friends, and others that can increase or decrease the perceived difficulty in performing certain behaviors. The more resources and opportunities an individual believes can have and the fewer obstacles that must be anticipated, the greater the perceived control over the behavior.

Perceived behavioural control has two aspects: how much a person feels to have control over behavior and how someone feels they can do or not do a behavior. In other words, the higher the control a person feels in carrying out a particular behavior, the stronger the person's behavior will be to do it.

\section{Switching Intention}

Switching intention represents consumers' migration from one service to another (Bansal et al., 2005). Switching intention is a signal of disconnection between customers and current services, either wholly or partially. Partial switching allows customers to maintain relationships with existing firms while adopting new behaviors. While it might be reasonable to assume that customers could be influenced to switch services due to a single event, many researchers suggest that the switch could also occur from various problems at hand (Ghamry \& Shamma, 2020; Riptiono et al., 2020). 


\section{METHOD}

This research uses a quantitative approach. The process of collecting data is by using questionnaires. This study's population were students of the Faculty of Economics, UIN Maulana Malik Ibrahim Malang class of 2019. The sampling technique in this study used purposive sampling. In this study, the sample criteria were students of the Faculty of Economics, UIN Maulana Malik Ibrahim Malang class of 2019 and did not have a sharia bank account.

This study uses confirmatory factor analysis because the variables in this study are based on the previous theory, namely the theory of planned behavior so that this study's results are not to develop or reduce new factors. It is different from exploratory factor analysis, where the factors to be tested are not determined in advance so that the results of the research will form or reduce them to new factors (Hair, 2014).

There are at least five tests in confirmatory factor analysis: First, the Kaiser Meyer Olkin Test (KMO) Second, the Measures of Sampling Adequacy (MSA). Third, Commonalities. Fourth, total Variance Explained. And fifth, the loading factor.

\section{RESULTS AND DISCUSSION}

In the description of the respondents' classification, it will be explained about the research subjects taken in this study based on gender and majors, and it can be concluded that the number of respondents with male and female gender has been obtained. The number of male respondents was 43 people, and female respondents were 57 people. This is sufficient in providing the statement items contained in the questionnaire and understanding and interpreting the statement items in the questionnaire. Furthermore, the number of respondents has been obtained from three departments of the Faculty of Economics. Respondents from management majors were 32 people, accounting for 30 people, and Islamic banking for 38 people. This is sufficient in providing the statement items contained in the questionnaire and understanding and interpreting the statement items in the questionnaire.

\section{Validity and Reliability Testing}

Table 1 showed that all items used in this study are valid because each item has a value of $r>0.195$. It can be concluded that the attitude, subjective norm, and perceived behavior control variables have valid items (Hair, 2014). It shows the reliability test. Reliability test also. Reliability test refers to an understanding that an instrument can be trusted enough to be used as a data collection tool because the instrument is good. The results of the reliability test using Cronbach alpha are as follows. The measuring instrument of all variables can be reliable and included in the very highreliability category because it has a Cronbach's alpha value above 0.70 . 
Table 1. Validity and Reliability Test

\begin{tabular}{|c|c|c|c|}
\hline Variable & item & $\begin{array}{l}\text { Corrected } \\
\text { Item-Total } \\
\text { Correlation }\end{array}$ & Cronbach'Alpha \\
\hline Attitude (X1) & $\begin{array}{l}\mathrm{X} 1.1 \\
\mathrm{X} 1.2 \\
\mathrm{X} 1.3 \\
\mathrm{X} 1.4\end{array}$ & $\begin{array}{l}0.932 \\
0.939 \\
0.936 \\
0.884\end{array}$ & 0.942 \\
\hline Subjective norm (X2) & $\begin{array}{l}\mathrm{X} 2.1 \\
\mathrm{X} 2.2 \\
\mathrm{X} 2.3\end{array}$ & $\begin{array}{l}0.896 \\
0.899 \\
0.768\end{array}$ & 0.818 \\
\hline $\begin{array}{l}\text { Perceived behavior } \\
\text { control (X3) }\end{array}$ & $\begin{array}{l}\text { X3.1 } \\
\text { X3.2 } \\
\text { X3.3 } \\
\end{array}$ & $\begin{array}{l}0.878 \\
0.898 \\
0.900\end{array}$ & 0.871 \\
\hline
\end{tabular}

Source: data processed by researchers, 2020

\section{Confirmatory Factor Analysis}

Confirmatory factor analysis consists some of the test. These are KMO and Barlett's test, Measures of Sampling Adequacy, eigenvalue, and loading factor. KMO and Barlett's Test shows that the KMO value is $0.859>0.05$ with a significance of $0.000<0.05$, so it can be concluded that the data has met the sample's adequacy. The Measures of Sampling Adequacy (MSA) shows that MSA value $>0.05$ so that the second requirement in this Factor Analysis is fulfilled and can be continued to the next test. The commonalities test shows that the variable must have a value greater than 0.5 , thus the value of the commonalities of each research variable explains that all variables used can be explained by the factors formed and have a strong relationship with these factors. Total Variance Explained show that 1 factor is formed that obtains eigenvalues $>1$ with a percentage of 80.15 . The cumulative $\%$ column shows the cumulative percentage of diversity that the factors can explain. The amount of diversity that can be explained by factor 1 is 80,152. From these results, it can be-concluded that one factor is sufficient to represent the diversity of the original variable. All value is shown by Table 2 .

Table 2 shows that factors shaping switching intention are attitude, subjective norm, and perceived behavior control. The loading factor value of attitude, subjective norm, and perceived behavior control $>0.55$. The attitude test results, and its indicators show that attitude and its indicators can influence and become a factor of switching intention in Islamic banks in Malang City. This can be seen from the loading factor value of attitude which is 0.920. Furthermore, subjective norm testing results show that subjective norms and indicators can influence and become a factor of switching intention on Islamic banks in Malang City. Then, the results of the perceived behavior control test and its indicators show that the perceived behavior control and its indicators can influence and become a factor of switching intention on Islamic banks in Malang City. Finally, the dominant factor's test results being the switching intention factor of Islamic banks in Malang City are the attitude with the highest loading factor value of 0.920 . 
Table 2. Confirmatory Factor Analysis

\begin{tabular}{|c|c|c|c|c|c|c|c|c|c|c|c|}
\hline \multirow[t]{3}{*}{ Variable } & \multirow[t]{3}{*}{ item } & \multirow[t]{3}{*}{$\begin{array}{l}\text { MSA } \\
\text { Value }\end{array}$} & \multirow[t]{3}{*}{ Extraction } & \multirow{3}{*}{$\begin{array}{l}\text { Loading } \\
\text { factor } \\
\text { indicator }\end{array}$} & \multirow{3}{*}{$\begin{array}{l}\text { Loading } \\
\text { factor } \\
\text { variable }\end{array}$} & \multicolumn{3}{|c|}{ Initial Eigenvalues } & \multicolumn{3}{|c|}{$\begin{array}{l}\text { Extraction Sums of Squared } \\
\text { Loadings }\end{array}$} \\
\hline & & & & & & & & & & & \\
\hline & & & & & & Total & $\%$ of & Cumulative & Total & Varianc & Cumulative \\
\hline \multirow{6}{*}{$\begin{array}{l}\text { Attitude } \\
\text { (X1) }\end{array}$} & X1.1 & $0.845^{a}$ & 0.746 & 0.864 & 0,920 & \multirow[t]{6}{*}{2.405} & \multirow[t]{6}{*}{80.152} & \multirow{6}{*}{80.152} & \multirow{12}{*}{$\begin{array}{l}2.40 \\
5\end{array}$} & \multirow{12}{*}{80.152} & \multirow{12}{*}{80.152} \\
\hline & $\mathrm{X} 1.2$ & $0.900^{a}$ & 0.776 & & & & & & & & \\
\hline & & & & 0.881 & & & & & & & \\
\hline & $\mathrm{X} 1.3$ & $0.821^{a}$ & 0.715 & & & & & & & & \\
\hline & & & & 0.846 & & & & & & & \\
\hline & $\mathrm{X} 1.4$ & $0.948^{a}$ & 0.799 & 0.894 & & & & & & & \\
\hline \multirow{3}{*}{$\begin{array}{l}\text { Subjective } \\
\text { norm (X2) }\end{array}$} & $\mathrm{X} 2.1$ & $0.855^{\mathrm{a}}$ & 0.695 & 0.834 & 0,904 & \multirow[t]{3}{*}{.377} & \multirow[t]{3}{*}{12.581} & \multirow[t]{3}{*}{92.733} & & & \\
\hline & $\mathrm{X} 2.2$ & $0.881^{\mathrm{a}}$ & 0.583 & 0.763 & & & & & & & \\
\hline & $\mathrm{X} 2.3$ & $0.849 \mathrm{a}$ & 0.561 & 0.679 & & & & & & & \\
\hline \multirow{3}{*}{$\begin{array}{l}\text { Perceived } \\
\text { behavior } \\
\text { control (X3) }\end{array}$} & X3.1 & $0.765^{\mathrm{a}}$ & 0.505 & 0.711 & 0,861 & \multirow[t]{3}{*}{.218} & \multirow[t]{3}{*}{7.267} & \multirow[t]{3}{*}{100.000} & & & \\
\hline & X3.2 & $0.806^{\mathrm{a}}$ & 0.568 & 0.754 & & & & & & & \\
\hline & X3.3 & $0.905^{\mathrm{a}}$ & 0.631 & 0.795 & & & & & & & \\
\hline
\end{tabular}

Source: data processed by researchers, 2020 


\section{Discussion}

Based on the results of the tests that have been carried out, it is known that attitudes can be a factor affecting switching intention in Islamic banks in Malang City. This could happen because many of the students are familiar with Islamic banks, although they are still not very deep. In addition, because all the students studied were Muslim, Islamic banks that had the label "sharia" associated with Islamic attributes were always perceived as positive. Even though it is still subjective. Regardless of whether or not students' perceptions of Islamic banking are accurate, establishing this attitude supports what is conveyed by (Ajzen, 1991) that attitude develops naturally from the beliefs held by someone. The formation of this belief is associated with specific attributes, for example with objects, characteristics, or other events. The results support the study of Farah (2017), Madahi \& Sukati (2016), and Youn et al., (2021), which stated that attitude is right and successful in influencing switching intention.

From the results of the tests that have been done, it is known that subjective norms can be a factor that influences the switching intention of Islamic banks in Malang. This means that there is a powerful influence from social factors that encourage the emergence of the intention to switch to Islamic banks. This vital social influence is influenced by referents/references given by people who are considered essential. People such as lecturers and colleagues are considered significant people and have the motivation to comply or influence arouse the intention to switch to Islamic banking. In addition, it could also be that social pressure to switch to Islamic banking is linked to religious authorities regarding orders to leave conventional banks that run their operations using usury. As stated by Budiman, (2018) that motivation to comply is also related to authoritarianism. The results support the previous researchers, Farah (2017), Madahi \& Sukati (2016), Youn et al. (2021) which found the research results that subjective norms were appropriate and successful in influencing switching intention.

From the results of the tests that have been done, it is known that perceived behavior control can be a factor affecting switching intention in Islamic banks in Malang City. This supports what was proposed by Ajzen (2002), and Levy \& Ben-Ari (2008) that perceived behavior control occurs because of perceived control, namely the perception or belief about whether or not it is easy to do something. Students' perceptions about switching to Islamic banking are still under control, or in other words, it is easy to do. This is evidenced by several question items related to the ability to switch to a sharia bank, and the results show that in terms of ability, both the time and ease of switching to a sharia bank can still be adequately reached.

The ongoing socialization has taken place among students of the 2019 Faculty of Economics at Malang regarding Islamic banking. Besides, it is also 
supported by facilities that make it easier to transition to Islamic banking. The frequent sharia banks made efforts to pick up the ball in serving student customers at the Malang Uin campus, and support from the Malang Faculty of Economics by establishing a sharia mini bank and several collaborations with Islamic banks to raise perceptions about easy to switch to Islamic banking. This is following the research that has been conducted. The results of this study support his research Madahi \& Sukati (2016), which states that perceived behavior control is appropriate and successful in influencing switching intention.

From the results of the tests that have been carried out, it is known that attitude is a dominant factor in influencing the switching intention of Islamic banks in Malang City. This study's results are different from the research conducted by Madahi \& Sukati (2016) that subjective norm is a dominant factor in influencing switching intention. The difference in the results of this study can occur as explained by (Ajzen, 1991) that in certain conditions, not only social pressure (subjective norm) is a consideration in playing an important role in behavior but more than that that personal Norm (attitude) also plays an important role, namely moral feelings in carrying out responsibility for certain tendencies in behavior. This is the desire to switch to Islamic banking.

According to Montaño \& Kasprzyk (2015), the tendency to be more attitudinal than normative (subjective norm) is also somewhat influenced by the age factor. Children who are given several choices for certain behaviors will prefer the values passed down by their parents. This is because children have a little well-developed defence mechanism, although these values will decrease with age. Meanwhile, older people will perform certain behaviors based on the evaluation of their perceptions. This research was conducted on students, the majority of whom are over the age of 16, so it is not surprising that the intention to do certain things, in this case switching to Islamic banking, is more dominant under attitudinal control than social pressure factors. In addition, because the intention to switch to a sharia bank is also something whose implication is more personal decisions, the attitude will be more dominant as a factor affecting the intention to switch to Islamic banks. This is confirmed by the statement (Azjen, 1980) that attitudes will be more dominant in predicting behavior intentions if it has attitudinal implications. Social norms will be more dominant than attitudes if the intention to perform certain behaviors has normative implications that is related to what many people need.

\section{CONCLUSION}

Based on the results of data analysis and hypothesis testing about the analysis of factors that affect switching intention in Islamic banks in Malang City, conclusions can be drawn. First, attitude can be a factor that influences switching intention. Second, subjective norms can be factors that influence switching intention. Third, perceived behavior control can be the factor that 
influences switching intention. Fourth, attitude can become the dominant factor in influencing the switching intention of Islamic banks in Malang City.

Research has limitations and weaknesses. Therefore, researchers provide suggestions for further researchers to develop this research in a larger sample with the hope that further research results are more reliable both theoretically and applicatively and by trying with other theories to get different results. Furthermore, for the management of Islamic banks to always pay attention to business aspects related to understanding customer behavior and providing treatment to each segment of its customers. This is to assist in formulating an effective strategy in reaching each different customer.

\section{REFERENCES}

Ajzen, I. (1971). Attitudinal vs. normative messages: An investigation of the differential effects of persuasive communications on behavior. Sociometry, 263-280.

Ajzen, I. (1991). The theory of planned behavior. Orgnizational Behavior and Human Decision Processes, 50, 179-211.

Ajzen, I. (2002). Perceived behavioral control, self-efficacy, locus of control, and the theory of planned behavior 1. Journal of Applied Social Psychology, 32(4), 665-683.

Ajzen, I. (2020). The theory of planned behavior: Frequently asked questions. Human Behavior and Emerging Technologies, 2(4), 314-324.

Ajzen, I., \& Kruglanski, A. W. (2019). Reasoned action in the service of goal pursuit. Psychological Review, 126(5), 774.

Ajzen, I., \& Schmidt, P. (2020). Changing behavior using the theory of planned behavior. Cambridge University Press: New York, NY, USA.

Arwani, A. (2015). Pengaruh sikap mahasiswa muslim terhadap minat pada bank syariah. Jurnal Penelitian, 12(1), 1-23.

Azjen, I. (1980). Understanding attitudes and predicting social behavior. Englewood Cliffs.

Bansal, H. S., Taylor, S. F., \& St. James, Y. (2005). "Migrating" to new service providers: Toward a unifying framework of consumers' switching behaviors. Journal of the Academy of Marketing Science, 33(1), 96-115.

Budiman, A. (2018). Blood Donating Behavior in Indonesia: Theory of Planned Behavior Perspective.

Dinaratu, D. A. (2017). Pengaruh Persepsi Mahasiswa Ekonomi Islam Tentang Kualitas Produk, Kualitas Pelayanan, Dan Nilai Syariah Terhadap Minat Menjadi Nasabah Bank Syariah [PhD Thesis]. University of Muhammadiyah Malang.

Farah, M. F. (2017). Application of the theory of planned behavior to customer switching intentions in the context of bank consolidations. International Journal of Bank Marketing.

Ghamry, S., \& Shamma, H. M. (2020). Factors influencing customer switching behavior in Islamic banks: Evidence from Kuwait. Journal of Islamic Marketing. 
Hair, J. F. (Ed.). (2014). Multivariate data analysis (7. ed., Pearson new internat. ed). Pearson.

Jabeen, S., Hamid, A. B. A., \& Rehman, S. U. (2015). Switching intentions: A case of saudi arabian hypermarkets. International Journal of Economics and Financial Issues, 5(1S).

Kaur, S., \& Arora, S. (2020). Role of perceived risk in online banking and its impact on behavioral intention: Trust as a moderator. Journal of Asia Business Studies.

Kotler, P., Kartajaya, H., \& Setiawan, I. (2019). Marketing 3.0: From products to customers to the human spirit. In Marketing Wisdom (pp. 139-156). Springer.

Levy, R. B.-B., \& Ben-Ari, M. (2008). Perceived behavior control and its influence on the adoption of software tools. Proceedings of the 13th Annual Conference on Innovation and Technology in Computer Science Education, 169-173.

Madahi, A., \& Sukati, I. (2016). An empirical study of Malaysian consumers' channel-switching intention: Using theory of planned behavior. Global Business Review, 17(3), 489-523.

Montaño, D. E., \& Kasprzyk, D. (2015). Theory of reasoned action, theory of planned behavior, and the integrated behavioral model. Health Behavior: Theory, Research and Practice, 70(4), 231.

Riptiono, S., Suroso, A., \& Anggraeni, A. I. (2020). Examining The Determinant Factors on Consumer Switching Intention Toward Islamic Bank in Central Java, Indonesia. Humanities \& Social Sciences Reviews, 8(2), 364-372.

Roos, I., Edvardsson, B., \& Gustafsson, A. (2004). Customer switching patterns in competitive and noncompetitive service industries. Journal of Service Research, 6(3), 256-271.

Youn, S., Lee, J. E., \& Ha-Brookshire, J. (2021). Fashion Consumers' Channel Switching Behavior During the COVID-19: Protection Motivation Theory in the Extended Planned Behavior Framework. Clothing and Textiles Research Journal, 0887302X20986521. 